\title{
8. \\ TUMAČENJE I PRIKAZIVANJE \\ INTELEKTUALCA-UMJETNIKA DANAS
}

\section{Zvonko Kovač}

UDK: $316.344 .32: 7.071$

Sažetak: U članku je analizirana uloga intelektualca-umjetnika u društvu općenito, s posebnim naglaskom na situacije u kojima se on osjeća kao stranac prema nacionalnom kulturnom i socijalnom kontekstu. Interpretirani su roman Tujci Ivana Cankara, uz iznošenje dosadašnjih tumačenja, kao i romani Povratak Filipa Latinovicza Miroslava Krleže i Povratak Filipa Latinovića Borisa Perića, koji se analiziraju u određenom intertekstualnom odnosu - kao predložak i njegova književna aktualizacija. Osim toga, članak se na kraju proširuje usporedbom sa sličnim romanima drugih južnoslavenskih pisaca - Oskara Daviča, Vladana Desnice i Marjana Rožanca, sa zaključnim osvrtom na postmoderno stanje.

Ključne riječi: prikazivanje (re-prezentacija), modernizam, intelektualac-umjetnik, obnova modernizma, južnoslavenske književnosti, postmoderna, povijest

\section{Umjesto uvoda: tumačenja umjetnika kod Cankara}

7 a razliku od izvrsne recepcije u Austriji, nekada vrlo poznato djelo Ivana Cankara danas se u Hrvatskoj ne čita, ni u modernističkom ni u postmodernističkom ili tranzicijskom $\square$ ključu. ${ }^{1}$ Za hrvatske prosvjetne vlasti, koje Hrvatsku žele vidjeti u mediteranskom ili srednjoeuropskom kontekstu, već više od dvadeset godina Cankar nije klasik srednjoeuropskoga kruga "bečke moderne”. On je kao i mnogi drugi klasici susjednih književnosti, poput Njegoša, Laze Kostića, Stevana Sremca ili Laze Lazarevića, Zmaja, Stankovića, Dučića ili Isidore Sekulić, Crnjanskog, Daviča, Miodraga Pavlovića, Selimovića, Kiša ili Pekića, isključen iz hrvatske srednjoškolske lektire, vjerojatno ne kao nepoželjan balkanski, nego više kao neprimjeren socijalni pisac. Ostao je u hrvatskome obrazovnom prostoru uglavnom kao "dječji pisac", s autobiografskom prozom Moje življenje, odnosno s crticama Skodelica kave i Suhe

1 Zvonko Kovač, "Recepcija slovenskega klasika pri Hrvatih”, Delo (Ljubljana), br. 113, 19. 5. 2010., 18. Usp. i: "Einen 'Klassiker der slowenischen Moderne' nennt Franz Haas den bis vor zehn Jahren auf Deutsch weitgehend unbekannten Autor Ivan Cankar (1876 bis 1918). Dessen Entdeckung würdigt er als Verdienst des Übersetzers Erwin Köstler und des Klagenfurter Drava-Verlags, der in zehn Bänden bereits die wichtigsten Werke Cankars veröffentlicht hat. Wie Hass berichtet, enthält sein nun vorliegender Roman 'Die Fremden', Cankars Erstling aus dem Jahr 1901, bereits das große Lebensthema des Autors - die Heimatlosigkeit der slowenischen Künstler zwischen Moderne und Volkskunst.” (http://www.perlentaucher.de/buch/ivan-cankar/die-fremden.html) 
hruške (iz staroga hrvatskog izbora Cankareve kraće proze Istina i ljubav). Na slabu recepciju Cankara kod Hrvata upozorio je još Jože Pogačnik u svojoj studiji Slovenski fenotip u hrvatskoj književnosti, u kontekstu opće teze o negativnom stereotipu, podcjenjivanju Slovenaca u hrvatskoj kulturnoj povijesti, posebno u književnosti. ${ }^{2}$ Potpuno različito od toga kako danas u Hrvatskoj (ne) čitamo Cankara i kako su na recepciju gledali kritičar i njegov interpretator, izvanredno je dobra bila modernistička recepcija Cankara kod hrvatskoga kritičara moderne Milana Marjanovića. Ona nije zanimljiva samo kao dokument znatnoga zanimanja za onodobnu suvremenu slovensku književnost i njezina pozornog čitanja među hrvatskim kritičarima i piscima u razdoblju moderne, nego i kao kritika u kojoj se stranac i stranstvo, a možemo reći samo drugi i drugost, vide u zanimljivoj dinamici razumijevanja "svojih tuđinaca", jednako kao u otkrivanju nerazumijevanja međuprostora u kojem djelujemo kao stranci neodvojeni od svoje domovine, a istodobno neprihvaćeni u drugome, stranom svijetu.

Slovenska književna povijest o Cankarevu romanu Tujci ne govori puno. Zanimljiviji su romani Na klancu i Martin Kačur, a najviše su eksponirani bili, dakako, Hlapec Jernej in njegova pravica te Cankareva socijalna dramska djela, koja su za našu generaciju bila obavezna lektira, slovenska kanonska djela. ${ }^{3}$ A kada se pisalo o romanu Tujci, naglašavalo se da se radi o prvome Cankarevu pokušaju pisanja romana koji je nastao na prijelazu iz ranoga razdoblja u zrelo razdoblje. Središnja je ideja romana, kako je pisao Janko Kos, da slovensko građansko društvo ne razumije umjetnika i novu slovensku umjetnost te zato umjetnik ostaje stranac u svojoj domovini, kao i u tuđini. Spomenutom povjesničaru nije bio po volji pesimistično fatalističan osnovni tijek romana, a zbog realistične osnove i impresionističkih psiholoških dodataka roman mu nije dovoljno umjetnički i stilski jedinstven. ${ }^{4}$ France Bernik, autor poznate monografije o Ivanu Cankaru, uspoređuje Tujce sa sličnim djelima o slovenskom umjetniku u tuđini, kao što su roman Križ na gori i Novo življenje. Čita ga na podlozi Cankareve biografije i izražava neprikrivenu simpatiju za Grivara iz pripovijesti Poslednji dnevi Štefana Poljanca na račun glavnoga lika Slivara u romanu Tujci, s obzirom na to da za razliku od njega kipar Grivar nikada ne pomišlja na samoubojstvo, nego ga doživljava samo kao "estetičku požudu", dok u sebi pobuđuje težnju za novim životom. Za razliku od Slivara, koji se kada ga žena napusti i prevari, baci u Dunav, "romantični iluzionizam Grivareve erotike” pripovjedač gradira tako "da se čini ispunjen, do kraja ostvaren”, slično kao u Grivarevu duhovnom životu.

Teološka vizija sveta, $\mathrm{v}$ kateri je vse naravnano $\mathrm{k}$ svetlobi in višjemu cilju, mu odkriva pozitivno vrednost duhovnega trpljenja, njegov smisel in etos. "Blagoslovljeno trpljenje - blagoslovljeno za paradiž!" Redkokateremu junaku Cankarjeve proze je romantično hrepenenje tako neizprosen imperativ in cilj hrepenenja tako blizu kot Grivarju, toda prav v trenutku najvišje hrepenenjske zanesenosti, sredi opisov, ki predstavljajo vrhunec pisateljeve lirsko romantične proze, se junaku porušijo sanje.

2 Nešto više o tome u: Zvonko Kovač, Međuknjiževna tumačenja, Zagreb 2005., 75.

3 O tome kako je Cankar u zajedničkim državama godinama figurirao upravo kao socijalno angažiran autor, zapravo kao klasik socijalne književnosti, dala bi se napisati opširna studija; uvjeren sam da mu je u Hrvatskoj baš to, da je bio povezivan sa socijalizmom, presudilo da ga više ne uzimamo kao kanonskog pisca, premda bi se druga djela, poput Hišs Marije Pomočnice ili Nina, danas mogla koristiti kao vrsne modernističke proze kakvih iz toga doba nema mnogo. Ne trebam ni spominjati da se slično dogodilo i domaćem piscu Augustu Cesarcu, iako su oba književnika u okvirima slovenske i hrvatske književnosti veoma važni pisci. Na žalost, zadnja provjera među studentima pokazuje da je i Vladan Desnica samo formalno na popisu hrvatske gimnazijske i srednjoškolske lektire.

4 Janko Kos, Pregled slovenskega slovstva, Ljubljana 2002., 217-218.

5 France Bernik, Ivan Cankar, Maribor 2006., 157. 
Nakon sloma ljubavne iluzije Grivaru je jasno da je živio u prošlosti, i to u sanjanoj, izmišljenoj zbilji, ali je unatoč tomu sposoban, za razliku od Slivara, "da nadmaši subjektivni idealizam i otvori se pravom životu", novom životu, a to je "povratak prema stvaralačkom radu, k umjetnosti". ${ }^{6}$

Manje zahtjevan prema romanu Tujci bio je Franz Zadravec, koji ga smješta u slovenski generacijski roman, a romaneskni "stranci" mogli bi biti Ivan Grohar, Rihard Jakopič ili Josip Murn iz tadašnje generacije, "kojoj su ljudi na vodećim mjestima, također kulturnjaci, preporučivali raditi u inozemstvu, jer Slovenija kao da nema novaca za umjetnost i znanost". Stranca ili narodnoga otudenika može se opaziti unutar dva kruga, u "domaćem krugu" i u "slovenskoj koloniji" - "njezin domaći dio se zauzima za vlast i kapital te produktivne umove odguruje u inozemstvo, a kolonijalni dio se cinično i dobrovoljno presađuje u druge nacionalne sredine". ${ }^{8} \mathrm{Na}$ kraju, kako zaključuje Zadravec, Slivar upozorava nacionalne nihiliste i provincijalne dogmatike da je bolje odreći se umjetničkih vizija nego ih zamijeniti za estetiku "narodne umjetnosti" i "malograđanskoga neukusa". $\mathrm{Na}$ pitanje zašto je Slivar učinio samoubojstvo, Zadravec ne odgovara.

Zanimljivo je da je vrlo rana slovenska kritika Cankareva romana Tujci spomenute narodne odrođene umjetnike imenovala - bastardi, dvojne građe, uvijek u disharmoniji, koji djeluju nesigurno i strano, a ne prisno, na koje je, doduše, narod djelomice ponosan, a koji, pak, već jedva lome materinji jezik, o domaćim prilikama govore "objektivno", distancirano, itd. Na taj način o romanu je pisala Zofka Kveder-Demetrović, i sama slovensko-hrvatski bastard, međukulturna spisateljica, te drugom prilikom dodala:

Ova je knjiga bolni, ali samosvjesni odgovor staroj inteligenciji, starim umjetnicima, literatima i političarima na sve one napadaje, kojim krste ljude, što odišu novim duhom, odgovor je jednog "moderniste". Neutaživa je to analiza njihova lažljiva patriotizma i nemoći! ${ }^{10}$

Za moje razumijevanje modernističkog čitanja najzanimljivija je spomenuta kritika romana Tujci Milana Marjanovića, objavljena u Obzoru 1903. godine, prva kritika, posebna po oduševljenome prijemu. Cankareva pripovijest pobuđuje na razmišljanja koja pogađaju u jezgro stvari i koja govore neku višu istinu, premda čitatelja ostavljaju u gorkom raspoloženju i "odišu pesimizmom".

Cankarova pripoviest spada u red onih djela, koja čitaoca pobudjuju na mnoge misli, koja ga sile, da se dublje zamisli u svoj zadatak, da ozbiljno razmišlja o svom položaju prama životu, a osobito prama svom narodu. To je jedno između onih, u literaturama ne baš tako mnogobrojnih, djela, koja pogadjaju u jezgro stvari i koja sile kategorički svakoga, da otvori oči i da se ozre oko sebe, koja trgaju s očiju koprenu, koja razodkrivaju svu istinu i tom cielom istinom izlaze pred čitaoca i traže, da ju gleda i da razmišlja o njoj. ${ }^{11}$

Marjanović se pita tko su stranci o kojima piše Cankar i odmah odgovara da je to sva slovenska inteligencija, posebno umjetnici koji žive između rodne grude i velikoga svijeta, koji su po imenima domaći, a u duhu i u svojim djelima su stranci. Jednako je u Beču - pripadnici "slovenske kolonije" "za svoj narod" su stranci, tako da su obje skupine u nekome

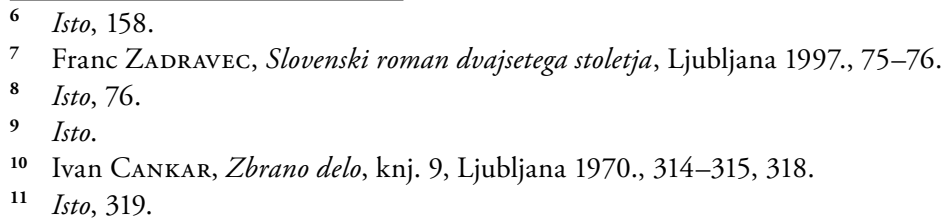


međuprostoru koji je neproduktivan, kako je uvjeren Marjanović, jer sredine nema, sredina vodi u smrt ili do boemstva i rezignacije. Cankar je imao hrabrosti postaviti jedno od temeljnih pitanja, odnos između inteligencije i naroda, te istodobno stvoriti djelo "neobične umjetničke ciene", na koje Slovenci mogu biti ponosni.

Sve je tu pisano onim čarobnim stilom, koji je uspjela sinteza realizma i začarane blage romantike. Sve je tu između sna i jave. Likovi su klesani, dialozi markantni, opisi sjajni i puni tople i krasne poezije. Nekoji su se ustručavali odrediti Cankaru mjesto u savremenoj slovenskoj literaturi, ali nakon ovoga djela može mu se bez oklievanja odrediti prvo mjesto medju živećim umjetnicima. ${ }^{12}$

Ne navodim to samo zato što vidimo oduševljenost hrvatskoga kritičara, nego i zato što sam uvjeren da Marjanović vidi pitanja koja otvara i kao probleme svoje kulture, odnosno hrvatskoga društva, pa se slobodno možemo upitati nismo li ponovno u situaciji u kojoj se od najboljih među nama očekuje prilagođavanje i zaboravljanje svoje kulture, u najmanju ruku možda i pristajanje na njezino konačno nestajanje. Naime, u nastavku svoje rasprave Marjanović se uhvatio problema maloga naroda, jer se Cankar našao, prema kritičarevu mišljenju, oči u oči sa suštinom tog problema.

Kod malog naroda - osobito takvog naroda, koji nema za sobom velike tradicije - sve je maleno, dapače maljušno, a iz malenoga se, dok ostaje maleno, ne može roditi ništa veliko ili ako se i rodi, to se nije rodilo njegovom zaslugom, te bježi daleko, van u veliki svijet, gdje ima više pobuda, više hrane i gdje dobiva više poleta. Ali onda taj mali narod biva lišen najboljih svojih sila, lišen onih veličina, koje bi mogle i njegovoj egzistenciji dati smisao i njegovom životu zadatak. ${ }^{13}$

U slučaju da je obratno te talentirani pojedinac ostane doma, on izgubi svu energiju u borbi s "maljušnim prilikama" te je korist vrlo relativna, jer narodima daju smisao i sadržaj u kulturnoj utakmici samo njegovi velikani! Ili izrijekom:

Slivar je htio nekako da ipak spoji te krajnosti, ali i on je tudjinac, tudjinac je kod kuće, jer donosi kući novi svijet, nove misli, koje oni kod kuće odmah prepoznaju kako tudje, a on ne može da se pritajuje, da ugrezne i laž i blato i - mora u svijet. U svijetu je opet tudjinac, jer još uvijek nije sasma prekinuo sa domovinom, jer nije sasma "stresao prah sa obuće svoje" i ne prima ga ni tudji svijet. Polutanstvo ne uspijeva u životu, u njemu uspijevaju samo izrazitosti. ${ }^{14}$

Za Marjanovića nije izlaz ni u relativnim veličinama, kojima smo u malim kulturama tako skloni, jer to rađa "zadovoljavanje s malim", što narod uspavljuje i slabi njegovu unutarnju snagu.

Pridodamo li k tome još odgojem nametnutu poniznost i skromnost, koja u tom slučaju postaje nekom megalomanskom, gotovo hinjenom skromnošću - onda dobijemo za rezultat ono neko samozadovoljstvo što vodi do mirovanja, do filistarije, do smrti. ${ }^{15}$

Što je rješenje, što nam je raditi? Marjanović zajedno s Cankarem odgovara: trebamo spoznati svoju malešnost i odbaciti poniznost, jer malen će narod prevladati i nadoknaditi "pomanjkanje mnogobrojnosti svojih članova i tjesnoću svoje kuće" samo s intenzivnosti

\footnotetext{
12 Isto, 322.

13 Isto, 337.

14 Isto, 337, 338.

15 Isto, 339.
} 
života, razvijanjem napetosti življenja, individualiziranjem društva. Kao što je to uspjelo sjevernim malim europskim narodima. ${ }^{16}$

\section{Dva Filipova povratka}

Filip Latinovicz Miroslava Krleže vratio se iz Svilarova svijeta kući nakon dvadeset i tri godine kao slikar pun dvojbi oko vlastita talenta i oko tendencija suvremene umjetnosti, $s$ naglašenim frustracijama iz djetinjstva i rane mladosti, u potrazi za izgubljenim identitetom. Diskontinuitet osobnosti koja samu sebe promatra nakon jedanaestogodišnjega kontinuirana izbivanja iz kaptolske kavane, u svemu je naglašen. On sumnja u identitet "svoje vlastite egzistencije", pitajući se o sebi kao o subjektu koji, na naratološkom planu, jednom preispituje samoga sebe kao lik, da bi se odmah zatim od takvoga sebe distancirao prepustivši auktorijalnom pripovjedaču da s čitateljem uspostavi savez u kojemu on neće uvijek pitati tko govori, subjekt lika ili narativni subjekt.

Gdje nam je dokaz, da naše "ja" traje, da smo "mi" još uvijek trajno i neprekidno "mi", gdje nam je zapravo mjera. Da on kao subjekt nije otputovao definitivno iz ovih prljavih i zaostalih prilika, kada je prije jedanaest godina posljednji put sjedio u ovoj smrdljivoj kavani, čekajući svoj vlak? ${ }^{17}$

Da nisu markirani navodnicima, mnogi bi se Filipovi monolozi mogli pripisati prvoosobnom pripovjedaču, kao i obratno, često se narativni subjekt i po stilu i po intenzitetu rečenice oslanja na Filipova razmišljanja, tako da se znakovi osobnosti i znakovi intelektualno-esejističkoga narativnog subjekta međusobno nadopunjuju i najčešće skladno razvijaju. Bilo da pripovijedanje teče iz perspektive narativnoga subjekta bilo da ga smjenjuju narativne dionice pisane iz perspektive lika, njihova međusobna blizina upućuje na autobiografski diskurs, barem kada je riječ o pitanjima umjetnosti.

Sve je bilo namješteno u Bobočkinu stanu kao u kazalištu (...) gdje se u dekorativnom polusvijetu pušilo, pilo i lagalo čitave dane i noći. (...) Lagalo se o knjigama, lagalo se o lirici, lagalo se o ukusu i o modi, govorilo se o Ljepoti, kao da je Ljepota naslovna stranica u trobojnom tisku kakvog ženskog pomodnog lista, i tako se lagalo i brbljalo, tako se trošilo mjesečno oko sedamdeset hiljada i tako su se razbila tri braka i propale dvije banke, a sve u nevinim razgovorima o Ljepoti, o Ukusu, o Vječnosti i o Bogu. ${ }^{18}$

Iako izrečene s kraja poglavlja u kojemu Filip upoznaje Kseniju Radajevu, prema intenzitetu kritičkoga odnosa spram društva u kojemu je zatječe, procjene o umjetnosti i o drugim vječnim pitanjima lako ćemo pripisati i glavnom liku iako nedvojbeno pripadaju angažiranom narativnom subjektu. Sličnih je mjesta mnogo i akademska ih je kritika već

16 Ukratko, zapisao sam prije slovenske krize, sto godina kasnije od dva mala južna, pretežno katolička naroda, moramo priznati da je manjemu to manje-više uspjelo, međutim bojim se da se u međuvremenu i on pridružio brojnijemu susjednom narodu, koji opet tavori između svoje izmišljene veličine i nametnute potrebe za poniznosti. Umjesto intenzivnosti života i individualiziranja društva - rezignacija, nirvana i fatalizam, u čemu prednjače samo još brojniji južnoslavenski balkanski narodi, poput Bugara i Srba, od kojih je, čini se, potonji izabrao, ratovima i dugom tranzicijom, još teži i naporniji put prema svojevrsnome povijesnom nepostojanju, kao jedinom izglednom načinu preživljavanja malih europskih naroda i kultura.

17 Miroslav Krleža, Povratak Filipa Latinovicza, Zagreb 1969., 46.

18

Isto, 143 . 
prije uočila. Za sličan postupak u romanu $N a$ rubu pameti Flaker će reći da roman ne čitamo prema bezimenom pripovjedaču, nego secundum auctorem, a Lasić da pisac teži "prelijevanju", njegova se misao utapa u misli lika i obratno. U svom istraživanju statusa refleksije u pripovjednoj prozi Krešimir Nemec princip "ambigvitetne narativnosti” povezuje s dvojnim karakterom refleksije u narativnome fikcionalnom djelu: priroda njezina iskaza uvjetuje njihovu autarkičnost jer se ne odnosi samo na poseban svijet literarne fikcije kojeg je dio, nego neposredno upućuju na predmetnosti koje objektivno postoje, na nešto "općevažeće" i "univerzalno". 19

Postupno smo tako došli do druge važne osobitosti re-prezentacije intelektualca umjetnika u književnosti, a to je naglašena intelektualizacija, odnosno esejizacija proze. Čini se potpuno prirodno da se pitanja umjetnosti o kojima narativni subjekt diskutira sa svojim likovima, odnosno kada preko svoga lika-umjetnika progovara i o autopoetičkim dilemama, iskazuju u esejističkome stilu. Portret umjetnika u mladosti Jamesa Joycea reducirajući fabulativnost, afirmirao je introspekciju i esejiziranje, dok se pripovjedač (iako u trećem licu) približio očištu lika o kojemu pripovijeda, a koji, diveći se ljepoti žene ptice, "spoznaje prostor umjetničke slobode i odlučuje da se pomoću umjetnosti uzdigne iznad mreža koje mu nameću njegova obitelj, nacionalnost i vjera” ${ }^{20}$ Kao što su problemi samoidentifikacije u prozama s likom umjetnika veoma važni, tako se čini da je i esejističko pripovijedanje važna reprezentacijska osnovica intelektualca općenito. Osim spomenuta Joyceova romana, koji je ocijenjen kao prvi roman engleskoga jezika u kojemu je predstavljena “žudnja za razmišljanjem”, ističu se slični romani europske književnosti, Očevi i sinovi Ivana Turgenjeva te Flaubertov Sentimentalni odgoj, jer je u njima predstavljena društvena stvarnost pod utjecajem novoga lika s kritičnim odnosom prema stvarnosti, dakle intelektualca. ${ }^{21}$

Ovdje se, uostalom, kao ključno teorijsko pitanje postavlja i samorazumijevanje pisca kao intelektualca, kao javno djelujuće osobe, bez obzira na njegov manji ili veći kritički angažman. Prema svemu sudeći, opet imamo posla s dvjema osobama ili s udvojenom perspektivom pripovijedanja zbog srodnosti problematike koja se tiče i pisca i intelektualca umjetnika, $s$ tom razlikom što će prema većini ostalih likova ili prema društvu u cjelini narativni subjekt zauzeti često nižerazredni rang opisa i karakterizacije. Naglašeno je kontrastivan esejistički diskurs Krležine proze, dakako ne samo u Povratku, prema onim osobnostima koje dolaze iz nižih slojeva ili nisu dio intelektualne rasprave, ali se aktivira u kakvom filozofu Kyrialesu s kojim intelektualna rasprava poprima i dimenzije izvanumjetničke problematike. Davno sam pisao o tome kako se Joža Podravec i Jaga, koji govore kajkavskim, teško mogu uključiti u te rasprave; oni su i stilski i svjetonazorno izvan svijeta i doživljaja umjetnosti koji tako razdire Filipov život. Istinskim esejističkim sekvencama, pa i traktatima o umjetnosti, kontrapunktira se nižim registrima života, kao i opisima slika u nastajanju, u njima kao da se halucinira stvarnost, odnosno vraća u realni svijet, kao u primjeru:

Filipu je bilo kao da je ušao u svjetlozelenkasti prostor jedne svježe, od ulja još mokre slike, i u onoj praznoj crkvi on je osjetio potrebu da podigne od unutrašnjeg uzbuđenja svoje obje

\footnotetext{
19 Krešimir Nemec, Pripovijedanje i refleksija, Osijek 1988., 52-53.

20 Dunja Detoni-Dujmić (ur), Leksikon svjetske književnosti: djela, Zagreb 2004., 507.

21 Edward SAID, "Predstavljanja intelektualaca", Odjek, 62/2009., br. 3 (jesen), 3.
} 
ruke, uznemiren i ponesen bogatstvom nove palete, što se pred njim otvorila kao kakva dragocjena okovana kutija. ${ }^{22}$

Smjena opisa onoga "što bi valjalo naslikati", što bi, dakle, tek trebala biti umjetnost, a koja je već ostvarena u dvojbenoj umjetnosti riječi, sa solilokvijima (naratora ili lika, svejedno) o umjetnosti, zapravo otvara onaj prostor koji je piscu romana s likom umjetnika od prvorazredne važnosti, a to je propitivanje vlastite umjetničke osobnosti kao umjetnika, pa onda i kao intelektualca. Naime, može se biti pisac, pa i angažirani pisac intelektualac, ali biti umjetnikom znači posjedovati neku višu moć ili znači biti obdaren talentom koji samo izabrane dovodi u vezi s umjetnošću, znači biti pjesnikom. A što je to intelektualac kao pjesnik i kako ga se može prikazati u prozi, ali i kako se on njome ovjerava, kakva je njegova pozicija i status u društvu - na to pisci najčešće odgovaraju likom drugog umjetnika, slikara, kipara ili glazbenika, ako misle o njemu ozbiljno kao o intelektualcu. Ako mu se pomalo autoironično rugaju, prikazuju ga u liku pjesnika ili propala pisca.

U kontrapunktu Filipove rasprave s Kryrialesom poezija i slikarstvo praktički se podrazumijevaju kao isto, pa je onda i njihova obrana vlastite "netjelesnosti" i "natprirodnosti", odnosno iskazivanje vjere u "čistoću umjetničke spoznaje” i talenta, praktički obrana obiju umjetnosti, i umjetnosti autora i umjetnosti lika. Narativni nas subjekt supostavljanjem dijametralno suprotnih stajališta tek diskretno (humanijim odnosom prema foringašu rasporene utrobe) pridobiva na njihovu stranu.

Umjetnost je talent, a talent je ono što nenadareni mozgovi ne mogu da pojme. Talent je snaga, koja se ne da objasniti ničim tjelesnim, ali isto tako ničim duhovnim, i te funkcije talenta su clairvoyantne i stoje iznad običnih funkcija razuma i tijela nedohvatno! ${ }^{23}$

Prikazivanja intelektualaca, pisao je Edward Said, njegova ili njezina artikulacija određenih problema ili ideja društvu ne znače primarno potvrđivanje ega ili slavljenje statusa. Također, ova prikazivanja principijelno nisu zamišljena da služe moćnim birokracijama ili darežljivim vlasnicima, posebno kada je riječ o intelektualcima umjetnicima. Prikazivanja intelektualaca su aktivnost sama po sebi. Ona zavise o svijesti koja može biti skeptična, angažirana, stalno posvećena nacionalnim ispitivanjima i moralnim sudovima. Zbog svega ovoga u središtu pozornosti uvijek je individualac. ${ }^{24}$

Drugačiji je individualac Filip Latinović naših dana Borisa Perića. Njegov Povratak odnosi se prema Krležinu predlošku kao daleki predak. Uokviren tek prvom i posljednjom rečenicom Krležina romana kao neposrednim citatima, Perićev roman preuzima sličnu, možda još i naglašeniju bliskost pripovjedača s Filipom, a dobro se uklapa u već afirmirani suvremeni esejizirani roman, kako po općem intelektualnom stilu tako i po nekim raspravama koje opet vode Filip i Kiriales. Dapače, čini se da Perić od Krleže najviše preuzima unutarnju napetost rečenice, pa i njezinu dužinu, kao znakove intelektualne superiornosti stila. Ni po čemu ne slijedi strukturu Krležina romana, premda malčice igra na kartu kontrastivnosti: naš novi Filip ne vraća se iz Europe na kaptolski kolodvor, nego iz Vrapča, gdje je u umobolnici proveo neke godine (trideset i dvije nemjerljive vremenske jedinice), a glavni prostori zbivanja u romanu nisu vezani uz hrvatsku provinciju, neki Kostanjevec, nego uz zagrebački Gornji grad kao simbol političke moći i simboličko središte Hrvatske.

\footnotetext{
22 Miroslav Krleža, Povratak Filipa Latinovicza, 35.

23 Isto, 115.

24 E. SAID, "Predstavljanja intelektualaca", 4.
} 
Ne trebam naglasiti da je Filipovo društvo u kostanjevečkoj provinciji bilo zapravo uzornije od Perićeva gornjogradskog, koje karakterizira brutalna tranzicija s ratnim posljedicama, globalni kapitalizam i nesnalaženje, svojevrsno opće postdludničko stanje. Njemu, na nejasnim granicama psihijatrije i psihoanalize, treba pridodati također određenu potragu za identitetom kroz traume djetinjstva i mladosti, spoznaje o majci kao trafikantinji i kurvi, odnosno sponzoruši, kao i Filipove probleme oko identifikacije s ocem, između stvarnoga i biološkoga oca.

Ovaj drugi, dr. iur. Zvonimir Krčelić, osvjedočeni domoljub i saborski zastupnik, u trenutku kad tutne hiljadarku Filipu u džep, izgovara ključne riječi o umjetnicima:

Eh, moj dragi dječače, da samo znaš koliko sam ja u životu znao zavidjeti vama umjetnicima! Vi smijete što želite, živite kako vas volja, nikakva društvena pravila za vas ne vrijede bez ostatka, dok za mene postoji samo dužnost, dužnost i opet dužnost. Ali za našu hrvatsku umjetnost nijedan izdatak nije previsok! ${ }^{25}$

Ili, nešto kasnije, nakon dubokoumne rasprave o oduhovljenju materije, kada se zaključuje da nema materije ni duha "i sve je samo gnjila pokisla žudnja", lik se našega slikara i pjesnika u svemu izjednačuje u pojmu intelektualaca kojih - više nema.

Filip je pogubio konce izgubio se u raspravi i zapravo mu je sasvim ugodno, hladnjikava kišica vani se raspadala, u birtiji smrdi, ali je toplo, i gle, pjesnik-aforističar nešto se osokolio, uzoholio, pa ustaje, uzima notes i hoće da čita, da podijeli svoj pjesnički zanos s dragom gospodom umjetnicima, prijateljima, sebi ravnim intelektualcima, kakvih danas, zapravo, više nema mnogo u ovoj opustjeloj vukojebini, gdje vuci jebu duh, a duh koga već stigne $(. . .)^{26}$

Društvene okolnosti u kojima živi i djeluje Perićeva društvena elita zajedno s Filipom jesu "siva stečajna masa" doma i međunarodni bankarski lobi u svijetu, a koje pregnantno izražava lokalni pjesnik-aforističar u stihovima: Cijelo selo oko bankomata / neveselo u kolo se lata! Tako se zarana spuštamo u hrvatsku tranzicijsku zbilju, kojoj je središte zapravo gornjogradska krčma Pod mirnim krovovima i alternativno prostori sado-mazo studija, koji vodi psihoterapeutkinja gospođa Ksenija Radović (Raday), a u kojemu pojedinci tjelesnim tretmanom istiskuju demona žudnje iz svoje "poremećene" psihe. Filipova samopotraga, njegov pokušaj povratka među zdrave i uspješne umjetnike, preko rasprava koje vode u evidentno kriminalnome miljeu, kao da bjelodano pokazuju razliku između Krležina Povratka Filipa Latinovicza kao europskog, svjetskog romana i Perićeva istoimena djela kao pravog romana domaće književnosti, upravo iz sredine, prisjetimo se Marjanovića, koja nije spoznala svoju malešnost i odbacila poniznost, odnosno koja nije išla prema intenzivnosti života, razvijanjem njegove "napetosti" i "individualiziranjem društva".

Perićev roman - napisan u jednome dahu, bez poglavlja is jedva uočljivim markacijama cjelina, gotovo kao gnjevni odgovor novomu društvu na prijezir koji ono gaji spram umjetnosti i umjetnika, na jednoj strani našli su se majstori privatizacije i politike novoga preokreta, a na drugoj umjetnički senzibilni intelektualci s iskustvom ludnice, bastardi $s$ nejasnim identitetom, ne od naroda odvojeni, nego s tim poremećenim narodom srasli propali umjetnici jednoga polusvijeta, društva u nestajanju - kao da potvrđuje Milanjinu radikalnu tezu da je postmoderna epoha suvremenom intelektualcu, pa i intelektualcu umjetniku, oduzela svaku građu, svaki materijal i svaki smisao djelovanja. Ona ga je na-

25 Boris Perić, Povratak Filipa Latinovića, Zagreb 2013., 146-147.

26 Isto, 146-147. 
prosto eliminirala kao suvišnu nepotrebnost ili stvar modernističke prošlosti. ${ }^{27}$ Zato nije čudno da za razliku od Krležina pripovjedača, koji s Baločanskim pregrize grkljan Bobočki, Perićev pripovjedač ubija i Krčelića i Filipa, s prethodnom Kirijalesovom psihoanalitičkom dijagnozom:

Ne znam ja, to vi znate. Možda kakvom šok-terapijom? Ironijom, hm? To vas ljuti, to vas vrijeđa? Ali to djeluje, to sjeda... Imala je Ksenija pravo, niste vi za puni tretman. Vama treba otac, strogi nemilosrdni otac, a ne darežljiva mati, koju idealizirate u sestri. ${ }^{28}$

Pa ipak, u nekome međuzaključku rekao bih, zajedno sa Saidom, da kao intelektualci po svojoj vokaciji trebamo biti u stanju neprestane budnosti i opreza, stalne želje da ne dopustimo konstantne promocije poluistina i nametnutih ideja; što sve implicira čvrsti oslonac na stvarnost, skoro atletsku energiju duha, kao i kompliciranu borbu da se uravnoteže osobni problemi sa zahtjevima objavljivanja i govora u javnoj sferi. ${ }^{29}$

Neskromno mislim da naši Desničini susreti tomu zaista umnogome pridonose, ne na zadnje i zato što u svojemu programu imaju umjetnika-intelektualca Ivana Galeba, koji sanja baš među slikarima da se negdje na rubu života ustroji i jedna "kolonija mislilaca", filozofa koji su samo prerušeni pjesnici.

Nesvjesni pjesnici, nehotični tvorci prave poezije. A njihovu pjesničku narav i suštinu potvrđuje i upotpunjuje baš i ta crta pjesničke naivnosti, pjesničke nesvijesti o samome sebi: što svoje vizije života i svijeta šaraju savršeno ozbiljna lica, kao djeca kad rišu. ${ }^{30}$

Ne bismo li se i mi povjesničari, barem teoretičari i povjesničari književnosti, mogli povesti za njima?

\section{Obnova modernizma - postmoderna: Oskar Davičo, Vladan Desnica, Marjan Rožanc}

Obnova modernizma pedesetih godina donosi nekoliko problematizacija lika umjetnika u suvremenim književnostima, najprije kroz propitivanje odnosa pjesnikova angažmana i revolucije, a onda i kroz likove umjetnika koji esejističkom meditacijom propituju same osnove karaktera umjetnika. Davičov roman Pesma bio je dočekan s oduševljenjem, između ostaloga i zato što što je donio "nov način prezentacije tematskog materijala ratne proze", a najveća mu se vrijednost pripisivala zato što je označio "konačno oslobađanje individualnog koncepta pripovedačke proze" te što je učvrstio "poljuljanu snagu literarnog junaka" ${ }^{31}$ Markantan ostarjeli pjesnik Andrija Veković, pripovjedačev alter ego, propituje svoje životne devize podjednako u pitanjima ljubavi, kao i oko problematike odnosa pjesničkoga stvaranja i samoće, krajnje individualnosti i slobode u ograničenjima koja donosi pripadnost pokretu otpora ili revoluciji. Najzanimljiviji dijalozi i pripovjedačeva razmišljanja, najčešće iskazana kroz lik Vekovića, koncentrirani su u svojevrsnom ljubavnom trokutu

\footnotetext{
7 Cvjetko Milanja, Čemu intelektualci u postmoderno doba, Zagreb 2011., 84.

28 Boris Perić, Povratak Filipa Latinovića, 219.

29 Edward SAID, "Predstavljanja intelektualaca", 5.

30 Vladan Desnica, Proljeća Ivana Galeba, Zagreb 1977., 87.

31 Predrag Palavestra, Posleratna srpska književnost 1945-1970 i njena istorija, Beograd 2012., $286-287$.
} 
između pjesnika, Ane i skojevca Miće Ranovića. Najprije, tu su njegove dileme oko ljubavi i spolnoga nagona - iako mu se činilo da je u potrazi za trajnom ljubavi "beskrajnu hiljadarku ljubavi proćerdao skucavši je u sitniš" ${ }^{32}$ Utoliko ga je više pogađala ljubomora kada se Ana odlučila za Miću, a najviše od svega bila je ugrožena njegova samoća, osamljeništvo.

Sve je to došlo nekako zajedno: radio-aparat, Mića, pesme, i Ana. Sve je to zajedno značilo nož u leđa nivou njegove samoće. Barbarstvo je i njega devalviralo. Ali drugačije se nije moglo živeti. A njegov život - dati se, dati sve, dati. Dati stihove, osećanja, sokove; zgrudvati celog sebe u slogove, u zagrljaje, u protest. Šta je drugo značilo njegovo prezrivo usamljeništvo? ${ }^{33}$

U potrazi za "emotivnim smislom" i potrebom za slobodom zaustavit će se tek na gordosti - "mrgodno, otrovno, korozivno stalno neraspoloženje", pa ravnodušnosti i animalnosti egzistencije. Susret s blizinom smrti najprije će iznuditi priznanje da je potratio život na žene, umjesto da sjedi i piše, da je pisao samo pjesme i ljubio život i da je trebao znati da govornici i generali govore horizontalno, savješću građana, a on je pjesnik i njegove su riječi vertikalne.

Pesnici govore na slušalicu vertikale vremena, gde se rešavaju pojasevi i pojasevi ljudi koji dolaze i gdje su zadaci - pretpostavke, lepote - mogućnosti i nejasne slutnje. Ako ih živi čuju - dobro, ako ne - svejedno. Čuće možda nerođeni. ${ }^{34}$

Ako je u odnosu na političare i oficire, u odnosu na savjest građana, pjesnik-intelektualac u etičkome smislu ispred svojega vremena, pa onda najčešće i s njima u nesporazumu, prava se drama njegova odnosa prema oficiru-intelektualcu iz redova okupatora javlja kada se i on odluči na akciju, kada biva uhapšen. Vekovićev razgovor s neprijateljskim njemačkim oficirom Klausom, u kojemu Davičo potonjem dozvoljava da iznese razloge svojega angažmana, davno je već zapažen i aktualiziran kao poseban primjer reprezentacije rata u modernome romanu, ali on ima još jednu dimenziju: pjesnikovu šutnju, pokušaj bijega i ograničenje godinama. Pedesetšestogodišnji pjesnik na kraju romana kao u svojemu ogledalu gleda uhapšenu majku s djetetom, sve se nadajući da će i on pred njezino strijeljanje napisati svoju najljepšu pjesmu, ali ne može jer je sada samo borac.

Svaki pesnik umire s nenapisanom pesmom, boljom od svih koje je napisao. Te pesme su antologije koje crvi vare u svojim crvljivim crevima. Šta vredi. On više nije pesnik. Prinuđen je da se bori i da bude samo borac. I biće. Biće borac kao što to nije još bio. ${ }^{35}$

Pjesnikova samoanaliza gotovo se simultano isprepliće s nesigurnim glasovima pripovjedača, pa često čine isti sugestivni sklop razumijevanja pisca, kao intelektualca-umjetnika, sa svim dilemama oko uključivanja u pokret otpora, odnosno oko angažmana. $\mathrm{Na} \mathrm{kraju}$ će mladi skojevac Mića, jedini poginuli u akciji spašavanja pjesnika, obojici i svima nama biti nedvosmislenim znakom moguće cijene ili ishoda borbe.

Različito od Daviča, već pomalo ostarjeli pisac Vladan Desnica kroz lik oboljela glazbenika u romanu Proljeća Ivana Galeba retrospektivno gleda na rezultate svojega življenja protekloga bez naročita društvena angažmana. U meditacijama, u prisjećanjima koja dozivaju pripovijedanje te u esejizacijama koje sjećanju daju gotovo pa gnoseološke iskustvene okvire, naglašeno intelektualni narativni subjekt, koji svojemu glavnom liku intelektualcu,

\footnotetext{
32 Oskar Davičo, Pesma, Zagreb 1968., 107.

33 Isto, 112.

34 Isto, 373.

35 Isto, 520.
} 
reproduktivnom umjetniku, otvara i intuitivnu, osjećajnu stranu zajedničkoga iskustva, posebno u završnim poglavljima u kojima neposredno progovara zapravo Desnica kao pjesnik (citatima iz vlastita pjesništva), odvija se unutarnja drama bolesna čovjeka suočena sa smrću. Njegova pomirenost sa životom ne proizlazi iz osjećaja ispunjenja svoje profesionalne ili životne situacije, nego baš obratno - iz spoznaje o relativnosti vrijednosti, slučajnosti uspjeha i skrajnutosti intelektualca-umjetnika od svih zbivanja u društvu. Ne kao romantičnih donkihota, neshvaćenih pjesnika, već više kao postmodernističkih intelektualaca koji zapravo nisu potrebni jer ih "imanencija postmodernističke paradigme eliminira i čini nepotrebnim”, pretvarajući ih ili u slabe neautentične subjekte ili u zagovornike loše politike. ${ }^{36}$

Smješteni u "polumračnoj dubini podno pozornice, negdje odmah pod lijevom rukom dirigentovom", i violinist i pripovjedač će, u posrednom kontaktu s javnošću, s "teatrom", u raznim stupnjevima dostojanstva odnosno poniženja, ${ }^{37}$ a to je i više negoli dobra slika smještenosti suvremenoga umjetnika u društvu, i kod onih na pozornici i kod sebe otkriti "čar samoće" kao jednu od glavnih osobitosti intelektualca-umjetnika. Bez ambicije da se upustimo u kompleksno tumačenje Proljeća kao romana o ostarjelom reproduktivnom ili postmodernističkom umjetniku, što pomalo isto znači s obzirom na to da se istinska postmodernistička umjetnost krije u kreativnim nadinterpretacijama ili reciklažama starih majstora, pa se koncentriramo samo na XXVI. poglavlje, na onaj po sjećanju reproducirani dijalog Ivana sa slavim glumcem, koji pomaže i glavnomu liku i pripovjedaču da na umjetnost $\mathrm{i}$ umjetnike gleda s manje zanosa i poštovanja. Dijalog započinje raspravom o djelima dramske poezije koja, prema mišljenju lika-pripovjedača, ne bi trebalo izvoditi, kojima "scenska realizacija" nije potrebna jer im oduzima nešto od njihove samodovoljnosti i dorečenosti. Suprotstavit će artificijum izvedbe i liričnost kao dvije oprečnosti i izvesti uvjerljivu argumentaciju prema kojoj istinska dramska i glazbena djela žive od svoje umjetnosti, dok umjetnost teatra živi od laži, lažne poezije. Nedugo zatim eksponira se i pitanje taštine, jer glumac priznaje da ga je u njegovu radu vodila želja za isticanjem, "za ekshibicijom svoje ličnosti”.

Kod nas, u našoj struci ta nabubrelost svog slijepog i golog $j a$, golog i čistog od svakog drugog svojstva, odlike ili sposobnosti, već samo po sebi predstavlja jedan od bitnih uslova za uspjeh. Drugi bitni uslov ili kvalitet jest: komedijanstvo. Prisustvo jedne primarne pelivanske, komedijantske sklonosti i umješnosti u nama. Ili čak čisto organske potrebe za lakrdijanjem. To je ono što bismo mogli nazvati zanatskim uslovima, osnovnom podobnošću za taj zanat. ${ }^{38}$

Sve to vrijedi i za glumca od formata, "intelektualiziranog umjetnika", a čitano u svrsi otkrivanja karaktera umjetnika intelektualca općenito, mirne duše te osobitosti možemo upisati i u njegove osobine. Premda će se Ivan s pripovjedačem suprotstaviti tomu, jer iskustvo strpljiva glazbenika-reproduktivca i pjesnika opominje da prava slava dolazi "tek onda kada smo izgubili smisao za njena zadovoljenja", njezini zraci padaju na nas kao "zimsko sunce koje obasjava ali ne grije”, baš suprotno, prava poetska riječ provaljuje iz nas kada je oslobođena svake sujetne preokupacije, tek pošto je popustio grč našega htijenja. ${ }^{39}$

Nakon pokušaja usklađivanja stavova i obostrane šutnje glumac u poduljem monolo$\mathrm{gu}$, zajedno s Ivanom i pripovjedačem, pokušava dati "konačne" spoznaje o umjetnosti i

\footnotetext{
3 Cvjetko Milanja, Čmu intelektualci u postmoderno doba, 43, 46.

37 Vladan Desnica, Proljeća Ivana Galeba, 203.

38 Isto, 208.

39 Isto, 210.
} 
umjetnicima. Od početne misli da se umjetnošću liječimo od života, pa i one da svakog iole pametnog vodi izvan nje - "prestanak umjetnosti putem njene sublimacije", glavna se teza formulira kao nešto suprotno sublimaciji umjetnosti, da umjetnost nije ono čudo u koje smo nekad vjerovali, da je ona nešto mnogo skromnije od onoga što je "zažarenost mladenačke egzaltacije" ispjevala, učinivši od nje istinu iznad svih istina, nešto iznad samoga života. Nakon smrti boga nastale su razne metafizičke koncepcije umjetnosti, koje su trebale pomoći osmišljavanju života, umjetnost je postala gotovo "tajanstveno nadnaravno otkrivenje", čemu pridonose najsuvremenije teorije podsvijesti, iracionalnog i intuicije. Bijeg od umjetnosti, ostajući još uvijek u njezinim granicama, s iluzijom da se odustajući od primarnoga poziva uspinjemo za stupanj više, krajnja je samoobmana (kad glumac "naginje režiji", kad se virtuoz "promitari u dirigenta", odnosno kad slikar "isklizi iz svijeta pojavnoga i ćutilnoga" te slika svoje misli ili kad pisac "nadraste" književne forme i ispunja dnevnike, zapise i marginalije), koja je također samo simptom "potrebe da se izađe iz vlastite kože, da se dezertira s polja umjetnosti", znak gubitka vjere u svoju umjetnost ili u umjetnost uopće..$^{40}$ I ne na kraju, kako u zanosnom sabiranju glumca razumijemo, u umjetnosti preživljava tek velik umjetnik, osobnost koja u sebi "udružuje velik um, velik duh i velik talent", koji nadrasta sam sebe, svoju umjetnost i umjetnika u sebi. ${ }^{41}$

Majstorstvu Vladana Desnice, koji protagoniste toga razgovora smješta u provincijski varijete, u kojemu violinist svira s vremešnom klaviristicom, odnosno u oronuli kabare gdje su se u opskurnim uvjetima na kraju karijere sreli i glazbenik i glumac, a u kojemu isluženi glumac glumi u nekom skeču, nemamo što dodati, osim onoga što o intelektualcu-umjetniku čitamo na završnim stranicama romana (LXV. poglavlje), a to su (1) kontemplativnost, (2) dnevni obrok prirode i (3) dnevni obrok samoće:

(1) Potpuno se predati umjetnosti znači nešto kao zavjet siromaštva: odreku od volje i njenih postignuća. Znači prepustiti se rovarenju unutrašnjih sumnja i kolebanja, osjetljivosti i njenom rastakanju. A ako osjetljivost i fantazija nisu krv i meso umjetnosti, ne znam što bi drugo bila umjetnost. (... $)^{42}$

(2) U zelenoj prirodi, među drvećem i travama, osjećam da dublje i stvarnije živim. Obuzima me djetinjasta želja da načupam trave i lišća i da ih naslažem na vjeđe, kao blagotvornu masku nekog iskonskog zelenog narkotika. Popušta zažarenost na licu i sparušena vrelina na usnama. Grižnje se ućutavaju, jetka osjećanja tupe, jenjava grč htijenja, mekšaju obrisi nasušnoga. (...) I uskoro nalazimo načina da nadrastemo sebe. ${ }^{43}$

(3) Strani su mi i ljudi kojima je strana ljepota samoće. Oduvijek sam jedan dio mog svjesnog dana morao provesti sam. Bježao sam iz društva, otkidao dio vremena od nužnog odmora, čak i od življenja, da bih bio nasamo sa sobom. (...) U besprekidnom društvu istapa se naša ličnost. Da bismo saznali našu intimnu misao, da bismo načuli naš vlastiti glas, potreban je dnevni čas usamljenosti. ${ }^{44}$

40 Isto, 211-212.

41 Isto, 212.

42 Isto.

43 Isto, 299.

44 Isto, 300. (Kao da, na istom mjestu, malom narativnom digresijom, kojom pripovjedač dodatno osnažuje potrebu za nasušnim obrokom samoće, pridajući stranosti nemjerljiv čar ljepote, Desnica zaključuje našu uvodnu varijaciju o intelektualcu-umjetniku kao strancu: "I putovati treba sam. Putovati još s nekim znači nositi sa sobom jedan dio onoga što ostavljamo, oduzimati jedan dio čara onom nepoznatom čemu idemo u susret. Znači u isto mah otići i ostati. Lišiti se mogućnosti da budeš stranac. A koliko li ljepote u tome: biti stranac!”) 
Ukratko, do sve tri navedene projektirane osobitosti suvremenoga intelektualca-umjetnika, kako ih vjerojatno još i sam Vladan Desnica nije mogao uvijek prakticirati, do razmišljanja u pomirenosti s prirodom te do samoće i usamljenosti možemo prispjeti samo uz dnevni ili tjedni obrok dokolice ili odmora, koje je neprolazna tranzicija oduzela možda ne toliko umjetnicima koliko svakomu od nas, dakle "potrošačima" umjetnosti. Pa kako da onda danas s kulturom ili kulturo-prirodom dobro stojimo?

I posljednji je primjer u nizu, koji već s jasnije pozicije postmoderne sumira rezultate povijesnoga modernizma i obnove modernizma, kod nas manje poznati roman Umor (Ubojstvo), u Sloveniji veoma cijenjena domaćega esejista i romanopisca Marjana Rožanca. Riječ je o zanimljivome pokušaju da se na kraju osamdesetih podsjetimo Cankareva vremena, u liku hrvatskoga slikara moderne Josipa Lhotke, odnosno Josipa Račića (pisac je vjerojatno od glazbenika Frana Lhotke preuzeo prezime, a "zabunio se" i u godini Račićeve smrti Lhotka umire simbolične 1918. godine), te preispitaju povijesne i umjetničke silnice razdoblja unutar kratkog dvadesetog stoljeća, od Oktobarske revolucije do pada Berlinskoga zida, što se kod nas poklopilo sa stvaranjem i drugim raspadom Jugoslavije. Udešeno kao istraživanje mladoga povjesničara umjetnosti o zagonetnome samoubojstvu slikara, pripovijedanje uz političke diskusije o sudbini malih naroda progovara i o pitanjima predanosti umjetnosti, bez obzira na političke neprilike, odnosno o umjetniku bez političke, pa i nacionalne osviještenosti.

Josip Lhotka nije htio više slikati svijet kakav se prikazivao njegovim očevima, htio je prodrijeti ispod očigledne stvarnosti, tradicionalne oblike i ljepotu žrtvovao je "izrazu vihorne umjetničke duše”; ekspresionizam je za njega bio "intimni posjed”, nije prihvaćao njegove krajnosti, avangardnost i političnost, njegov kriticizam i odbijanje svijeta. A njegov se pesimizam hranio iz nepomirljive nasuprotnosti između čovjeka i svijeta, individualne osobe i društva. Stoga se pripovjedač slaže s istraživačem-profesorom da Lhotka nije prihvatio tada popularno schopenhauersko rješenje - odmak od svijeta, u nirvanu. ${ }^{45}$

Probijajući se kroz koncepcije umjetnosti i političke spletke, odnosno povijesna zbivanja, u petom poglavlju romana dolazimo do pobližega upoznavanja sa slikarevom umjetnosti: njegov je pogled bio samo jedan - iz lica u lice, iz sebe prema van, pogled na objekt kao objekt.

$\mathrm{Na}$ tujin nedostopen predmet, pa četudi gleda človeka, ki prav zaradi svoje nepredirnosti vzbuja v njem najbolj človeška čustva, tujstvo, nostalgijo, prekletstvo, vzporedno z njimi pa tudi slikarsko strast. ${ }^{46}$

$\mathrm{Na}$ kraju, sa slovenskim iskustvima obnove modernizma druge polovice 20. stoljeća kao da se gube razlozi za (samo)ubojstvo, a rastu razlozi za distanciranost i odustajanje; autor nas suočava s hrvatskom situacijom pred Prvi svjetski rat, uspoređuje Lhotku i Meštrovića, a čudi ga što se Lhotka nije sreo s Tinom Ujevićem, nego su obojica ostala u svojoj samoći, iako su si po umjetničkoj samotnosti i nezanimanju za realni svijet najbliži.

Samo samotni posameznik se lahko upre najstrašnejšemu od vseh gostov, nihilizmu in njegovi pustoti, končni točki krize, ki jo je Hölderlin poimenoval odsotnost bogov in Nietzsche smrt Boga. Upre temu, da bi človekov svet postal brezciljen in nem. Zakaj nihilizem je zmagoslavje človeka brez Večnosti, nesramnost svobode kot samozadostnosti, nesramnost

45 Marjan RožANC, Umor, Ljubljana 1990., 93-94.

46 Isto, 148. 
človeka, ki je izbral le samega sebe. Najpopolnejši izraz tega nihilizma, pa je nasilje enoumnosti. To je triumf razuma nad svobodo, inteligence nad posameznikom, prepričanja nad pomenom, programa nad človekom, zgodovine nad usodo (... $)^{47}$

Objavljen u osvit demokracije i osamostaljenja, ovaj roman po svojem idejnom iskustvu ne bi se trebao zanemariti ni u dobu kada su nade u demokraciju ponovno iznevjerene podjednako uskrsnućem boga i preporodom Crkve, kao i ovim ili onim oblikom nacionalne samodostatnosti i stranačkoga jednoumlja. Je li izlaz u Rožanc-Lhotkinu odricanju od stvarnosti te u odustajanju od svakog nacionalno-kulturnog ili političkog angažmana? Svejedno kako, mistično samoubojstvo prikazano kao ubojstvo tamnih sila povijesti govori nam ne samo o tome da bi trebalo modernizirati studij povijesti u naglašeno interdisciplinarnom smislu ${ }^{48}$ nego i o tome da su i umjetnici podjednako odgovorni za svoj život, kao i za tuđe. Potrebu za novom historijom kao "povijesnom antropologijom", u kojoj bi i slučaj Cankareva kipara Slivara kao i sudbina slikara Lhotke za razumijevanje svijeta mogli biti podjednako važni, prati i uviđanje pripovjedača o dragocjenoj ulozi intelektualca danas. U svijetu u kojem ugled uživaju "zvijezde iz poslovnoga svijeta i svijeta spektakla", intelektualci uglavnom šute, pa i kada progovore, nestrpljivo se upozore da radije ušute. Kod toga se događa nešto što je strašnije od svakoga totalitarnog mišljenja, a to je uvjerenje, koje je u odsutnosti istine i smisla uzdiglo zastavu gluposti i koje negotovost - nesigurnost, neizvjesnost, proglašava za zadnju mudrost, minimalizam za najbolji program, moral za nešto posve relativno... Od osjećaja da smo stranci u vlastitom društvu - slično kao i u inozemnom - do osjećaja da smo suvišni, proteklo je samo dugo dvadeseto stoljeće. Kako će biti u novom vijeku?

Ne bismo li se ipak trebali složiti s Rožancem, bez obzira na to iz čije perspektive govori, da je baš u takvu svijetu uloga intelektualca utoliko zahtjevnija, odnosno da je baš u trenutku kada nema više ni smisla ni konačne istine njegovo povlačenje njegova najveća pogreška? Smrt autora zapisa koji istraživanjem pozadine smrti Josipa Lhotke zapravo najavljuje svoju smrt, govori možda samo o smrti intelektualca-umjetnika, pjesnika, dok pripovjedači i povjesničari, kao i u ovome primjeru, žive dalje.

Za provjeru stanja, tumačenja i prikazivanja intelektualca-umjetnika danas bio bi potreban iskorak u komparativna istraživanja europske književnosti, od Thomasa Manna, već spomenutoga Joycea ili Prousta, Hermana Brocha ili francuskoga "novog romana", do Handkea ili Elfriede Jelinek, ${ }^{49}$ ali time bismo dvostruko prekoračili temu jer je za njegovo razumijevanje u hrvatskome društvu i umjetnosti dovoljna Perićeva intertekstualna relacija spram Krleže: umjesto Bobočke na samrti otvorenih očiju leži Filip, u tišini bez okusa, boje i mirisa, koja nije više tražila slikara da je naslika. Niti pjesnika ili znanstvenika da joj daju, razumiju ili objasne smisao.

$47 \quad$ Isto, 153.

48 Isto, 234. ("Zdaj šele vidim, kako neobhodno je pravzaprav prizadevanje profesorja Pelletiera, ki hoče tudi zgodovino podvreči vsestranskemu, interdisciplinarnemu pretresu, v katerem naj bi sodelovali filozofi in psihologi, fiziki in tehniki, če ne celo lingvisti, etnologi in podobni specialisti. Samo na ta način je mogoče preseči tradicionalno zgodovinopisje, ki se je doslej hranil in se še hrani izključno z enostranskimi političnimi dogodki.”)

49 Usp. Viktor Žmegač, Povijesna poetika romana, Zagreb 1987., 416-417. ("Modernizam, koji je svojim emfatičkim odnosom prema mogućnosti umjetnosti zapravo postupao u duhu mladoga Nietzschea, našao se u opreci prema Hegelovim prognozama. Danas se, međutim, njegova misao o budućnosti umjetnosti prikazuje u drugačijem svjetlu: misao da će u vremenima koja dolaze razmišljanje o umjetnosti biti primjerenije identitetu epohe nego sama umjetnost. Ako ta misao sadrži spoznaju o nužnosti da se umjetničko stvaralaštvo danas shvati kao oblik historicističke igre, onda je Hegelova sjena u ovome trenutku duža nego ikada.”) 


\section{$\cos$}

\section{The Interpretation AND THE Representation OF THE Artist-Intellectual Today}

This paper provides an analysis of the position of the intellectual-artist within society, focusing on situations in which the intellectual feels detached from the national cultural and social context. This is done on the examples of Ivan Cankar's novel Tujci (Foreigners; and the existing interpretations of that novel), as well as Miroslav Krleža's novel Povratak Filipa Latinovicza (The Return of Filip Latinovicz) and Boris Perić's Povratak Filipa Latinovića (The Return of Filip Latinović),which are analyzed through the intertetual relationship of source material and an adaptation. Perić's contemporary novel adopts, and even expands on, the narrator's closeness with Filip and fits well into the framework of the contemporary essay-like novel, both in terms of (a general intellectual) style and of the discussions style between certain characters. As the problems of author's self-identification are important in prose containing the character of an intellectual, so is essay-like narration, wherein the narrator and the characters switch roles, an important element in the representation of an intellectual. This paper also addresses similar novels by other Yugoslav writers - Oskar Davič, Vladan Desnica and Marjan Rožanac and ends with an overview of the postmodern situation. The novel Pesma (Poem) analyzes the poet-intellectual's relationship towards women and the revolution, as well as the issues of the timelessness of poetry and the artist's loneliness. Those issues take on a special meaning in the novel Proljeća Ivana Galeba (Springs of Ivan Galeb), which is laced with contemplation and "a daily dose of nature", as the implied common traits of all intellectuals. The novel Umor (Murder) addresses the issue of the artist-intellectual's right to commit fully to painting regardless of the historical and political situation, while questioning the meaning of the artist's retreat, i.e.the death of the poet in the age of postmodernism.

Keywords: Re-presentation, modernism, intellectual-artist, modernist revival, Yugoslav literatures, postmodernism, history

\section{$\cos$}

\section{Literatura}

France Bernik, Ivan Cankar, Maribor 2006.

Ivan Cankar, Zbrano delo, knj. 9, Ljubljana 1970.

Dunja Detoni-Dujmić (ur.), Leksikon svjetske književnosti: djela, Zagreb 2004.

Zvonko Kovač, "Recepcija slovenskega klasika pri Hrvatih”, Delo (Ljubljana), br. 113, 19. 5. 2010., 18.

Miroslav Krleža, Povratak Filipa Latinovicza, Zagreb 1969.

Cvjetko Milanja, Čemu intelektualci u postmoderno doba, Zagreb 2011.

Krešimir Nemec, Pripovijedanje i refleksija, Osijek 1988.

Predrag Palavestra, Posleratna srpska književnost 1945-1970 i njena istorija, Beograd 2012.

Boris Perić, Povratak Filipa Latinovića, Zagreb 2013.

Marjan RožANC, Umor, Ljubljana 1990.

Edward SAID, "Predstavljanja intelektualaca", Odjek, 62/2009., br. 3 (jesen), 3-9.

Vladan Desnica, Proljeća Ivana Galeba, Zagreb 1977.

Franc Zadravec, Slovenski roman dvajsetega stoletja. Prvi analitički del, Ljubljana 1997.

Viktor ŽMegač, Povijesna poetika romana, Zagreb 1987. 